\title{
FDA backs
} rosiglitazone -with warnings

\section{Janice Hopkins Tanne NEW YORK}

Two advisory committees of the Food and Drug Administration recommended this week that the FDA should keep rosiglitazone (Avandia), which is used to treat type 2 diabetes, on the market, despite concerns about the raised risk of heart attack in some patients.

Warnings will be increased, however, about use in subgroups of patients. Whether the warnings will be of the most serious "black box" type is yet to be determined. The FDA usually follows the advice of advisory committees but is not required to. The FDA will consider the committees' discussion and make recommendations for changes to labelling.

The FDA's advisory committees on endocrinological and metabolic drugs and the drug safety and risk management advisory committees met jointly at a crowded public meeting in a hotel near the FDA headquarters, outside Washington, DC, on Monday.

The FDA brought forwards its meeting to consider rosiglitazone's risks in light of a paper by researchers at the Cleveland Clinic that

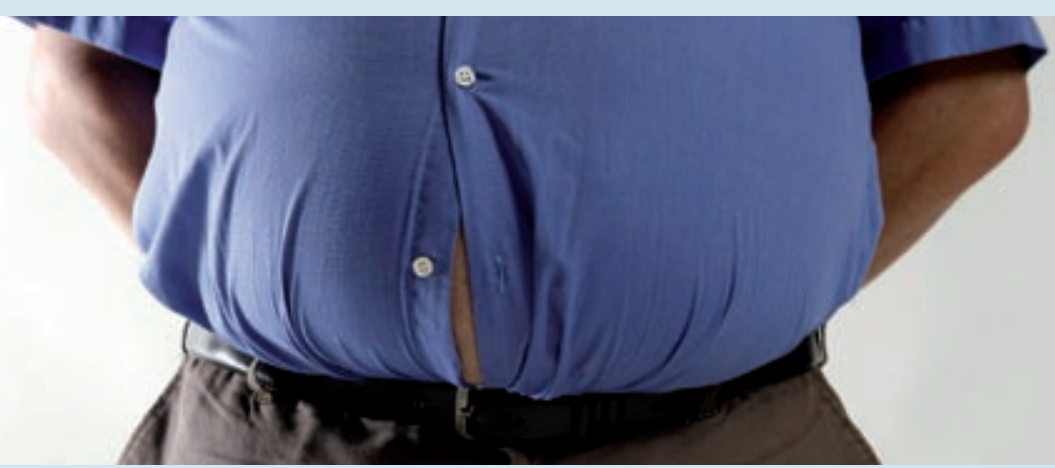

The drug should not be used in patients with cardiovascular disease, says FDA

showed a $43 \%$ bigger risk of heart attack among patients taking the drug (BM) 2007;334:1073 doi: 10.1136/bmj.39224.364630.DB and New England Journal of Medicine 2007 May 21 doi: 10.1056/NEJMoa072761).

The committee did not consider the increased risk of congestive heart failure with rosiglitazone and related diabetes drugs, which has been known about for several years.

It has long been known that both rosiglitazone and pioglitazone

(Actos) increase the risk of congestive heart failure. In June the FDA placed a black box warning about heart failure on both drugs (BM/ 2007;334:1237 doi: 10.1136/ bmj.39244.394456.DB).

The joint committees voted 20 to three that rosiglitazone posed a higher risk of cardiac ischaemic events, but 22 to one that rosiglitazone should stay on the market, albeit with greater warnings.

David Graham, associate director of the FDA's office of surveillance and epidemiology, told the committee that rosiglitazone should be pulled from the market because, he said, it had caused between 40000 and 205000 heart attacks and strokes since 1999.

His superior, Gerald Dal Pan, director of the FDA's office of surveillance and epidemiology, in the Center for Drug Evaluation and Research, said that rosiglitazone's risk-benefit profile was "not favourable." Robert Meyer, director of the FDA's office of drug evaluation II, said he was Warnings will be increased about use in subgroups of diabetic patients undecided about what regulatory action should be taken. He noted disagreements among FDA staff.

GlaxoSmithKline (GSK), the manufacturer of rosiglitazone, strongly defended the drug. It said that meta-analyses to determine the risk of ischaemic cardiac events, such as those by Steven Nissen and Kathy Wolski of the Cleveland Clinic in the New England Journal of Medicine study, studies by the company itself, and studies by the FDA "have significant limitations. GSK believes a full and scientific evaluation of all the data does not confirm the safety questions originally raised."

\section{Diabetes study shows nothing new}

Janice Hopkins Tanne NEW YORK Vivian Fonseca, the editor of Diabetes Care, told the BMJ that he was surprised by the media's interest in a study that says that rosiglitazone (Avandia) and pioglitazone (Actos) doubled the risk of heart failure in patients with type 2 diabetes (Diabetes Care 2007;30:2148-53 doi: 10.2337/ dc07-0141).

The authors said that although

\section{drugs in the thiazolidinedione} class were known to increase the risk of heart failure in patients with type 2 diabetes, the magnitude of the risk had not been evaluated. They used teleoanalysis to look at results from many different types of trials, involving 78000 patients, and concluded that one in every 50 patients with type 2 diabetes taking one of these drugs would develop heart failure in a period of 26 months and need admission to hospital (see $B M J$ 2003;327:616-8 for an explanation of teleoanalysis).

Heart failure occurred at low and high doses of the drugs and among people of all ages.

"These drugs are currently used by more than three million diabetic patients in the US alone, suggesting that several thousand could be harmed," said the lead author Sonal Singh, an assistant professor of internal medicine at
Wake Forest University School of Medicine, in North Carolina.

GlaxoSmithKline said that the paper "provides no new information on the risk of heart failure associated with the thiazolidinedione class."

"The risk of heart failure... with use of these medicines is well recognised and is clearly identified in prescribing information to doctors in the UK," said Alastair Benbow, European medical director at GlaxoSmithKline. 


\section{Patients need to have safeguards from unscrupulous fertility}

\author{
Michael Day LONDON \\ Professional guidelines are urgently needed to \\ prevent patients who are seeking fertility treatment \\ from being exploited by unscrupulous clinics, \\ according to a parliamentary committee. \\ The Joint Committee on the Draft Human \\ Tissue and Embryos Bill rejected core proposals \\ in the government's white paper on fertility \\ research and regulation and laid out key ethical \\ recommendations. \\ The committee's chairman, the Labour MP Phil \\ Willis, began with reproach for private clinics that \\ offer in vitro fertilisation (IVF). \\ "There is much anecdotal evidence, some of it \\ from members of this committee, that there has
}

been abuse of patients seeking help in private clinics," he said.

"We recommend that all patients be given fully costed treatment plans, and, given recent events, including a recent high profile court case, we think the Royal College of Obstetrics and Gynaecology should produce professional guidelines to protect patients from unproved treatments."

The committee said that some patients were being sold treatments that were "exorbitant in cost" and that provided "no practical chance of delivering a pregnancy to that particular patient." MrWillis has also dealt a blow to the Department of Health by rejecting its central proposal that the Human Fertilisation and Embryology Authority and the Human Tissue Authority be merged to form the Regulatory Authority for Tissue and Embryos. He said, "There are some very, very, serious issues for the government to take on board. The government will find it very difficult to bring in the current [draft] bill with amendments given the fact that it was not able to provide any real evidence to support its view that the two bodies be merged."

The committee's report notes that although the Human Tissue Authority was "concerned entirely with the policing of consent" the Human Fertilisation and Embryology Authority has "to deal with the much more complex moral and ethical issues surrounding the use of human embryos." Robin Lovell-Badge, of the Medical Research

\section{UK based Iraqi psychiatrist is named as country's latest health minister}

\section{Owen Dyer LONDON}

Iraqi doctors last week gathered in London with representatives of international relief agencies to discuss health policy and humanitarian aid efforts in their wartorn country. The Iraq Health Crisis Conference, organised by the health charity Medact, also heard from Sabah Sadik, a psychiatrist from Kent, whom the Iraqi government has named as the country's next health minister.

Dr Sadik, currently the medical director of Kent and Medway NHS and Social Care Partnership Trust, is expected to leave Britain this summer to start his new job. He is the sole nominee for the post vacated by Ali al-Shemari, one of six ministers loyal to Shiite cleric Moqtada al-Sadr, who left the government in April.

Last August US forces arrested seven bodyguards of Dr al-Shemari, accusing them of running a kidnapping ring. This February US forces arrested the deputy health minister Hakim al-Zamili in his office, citing his alleged involvement in the kidnapping and disappearance of fellow deputy health minister Ammar al-Assafar. Dr al-Zamili's own convoy was ambushed the day after Dr al-Assafar disappeared, killing two of his bodyguards.

In 2004-5 Dr Sadik spent a year in Iraq as national adviser on mental health. He will take on a ministry with a fearsome reputation for political violence and infighting. Dr Sadik told the BMJ, "A lot of peopleespecially Iraqis-have told me I'm crazy."

Delegates heard that since 2003 unidentified groups have prosecuted a campaign of murder and intimidation of health professionals in Iraq, which initially targeted doctors and academics, but has recently claimed more nurses and medical students. Amir al-Mukhtar, a former director of the Medical City hospital, in Baghdad, said that medical students in Baghdad now rarely attend courses.

Jose Francisco Duda of the International Committee of the Red Cross said workers have experienced kidnap, attack, and death in the process.

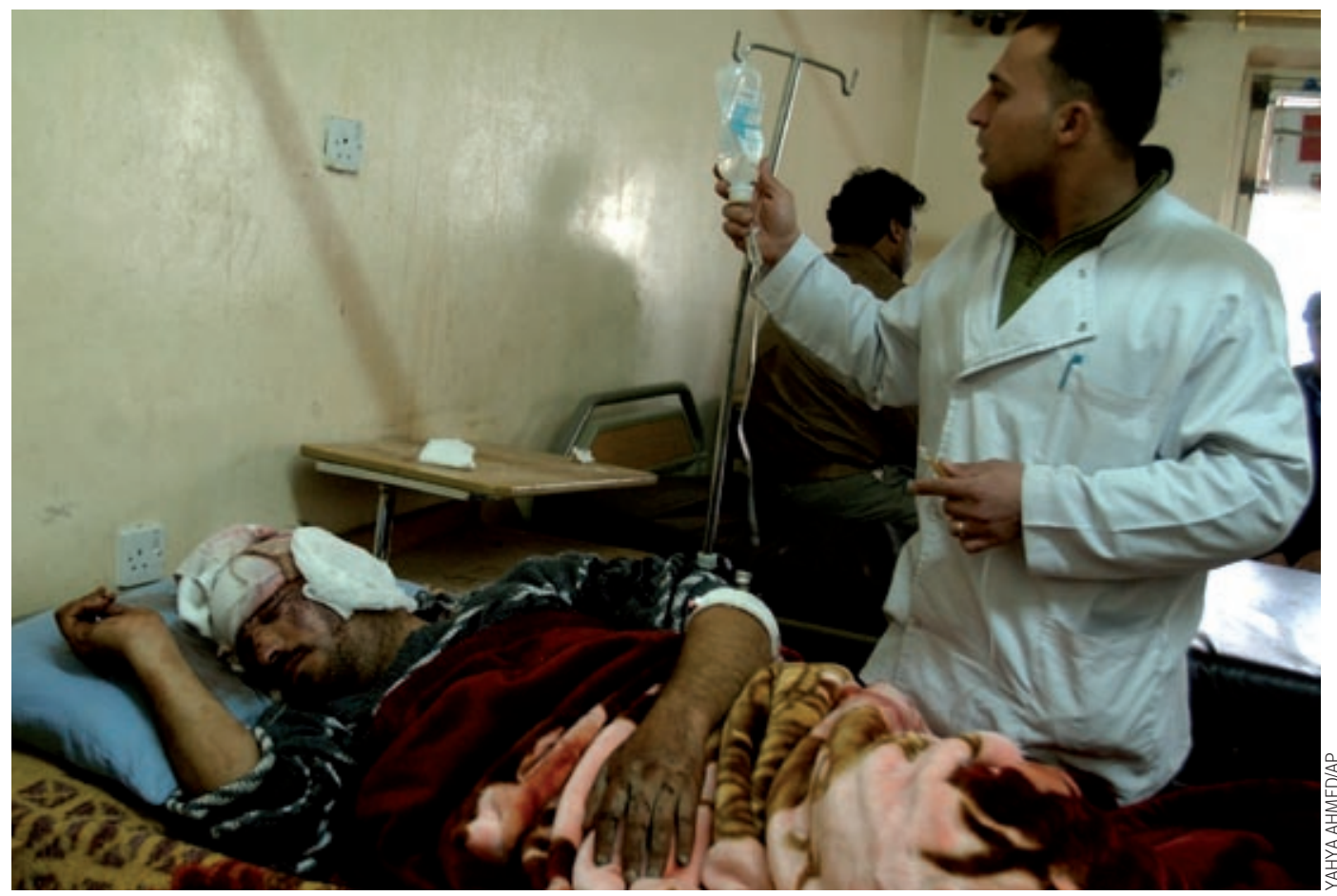

A doctor checks a patient injured by a car bombing in Kirkuk, 290 km north of Baghdad, in January 


\section{clinics, says report}

Council, said, "I fully support their rejection of the merger. This would create a chimeric body far more troubling than any that I can imagine making in my lab."

Mr Willis also called for donor conception to be automatically mentioned on a child's birth certificate. Fellow committee member Lord Mackay said, "It's an act of deception by the state for them to go through their life without knowing their origin."

Mr Willis added, "If parents wish to deceive their children, that's their decision but we feel the state should not be complicit in this."

The report is available at www.parliament.uk/ parliamentary_committees/humantissue.cfm.

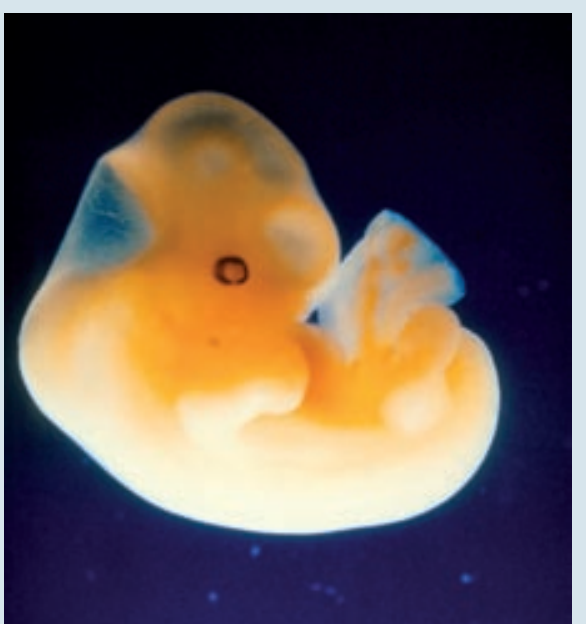

A 5 week old embryo: MPs have rejected plans for a single embryology and tissue authority

\section{Court overturns race discrimination ruling against BMA}

\section{Clare Dyer BMJ}

A record race discrimination award against the BMA won five years ago by a surgeon who qualified in India was overturned last week by three appeal court judges.

Rajendra Chaudhary was awarded $£ 814877$ (€1.2m; \$1.7m) compensationthe highest ever for a race discrimination claim-by an employment tribunal in 2002 for the BMA's failure to support him in claims of race discrimination over his specialist training. The finding was upheld by the Employment Appeal Tribunal in 2004 (BMJ 2004;328:786 doi: 10.1136/bmj.328.7443.786-a).

But last week the appeal court judges said that the BMA had refused to back his claims not because of race discrimination, but because the claims were not well founded.

Lord Justice Mummery, delivering the unanimous judgment of the court, said, "The essential ground is that no reasonable tribunal . could have concluded that the BMA was guilty of indirect race discrimination against Mr Chaudhary or victimisation of him.”

$\mathrm{He}$ added, "The crucial point is that $\mathrm{Mr}$ Chaudhary's allegations of race discrimination against him by the regulatory medical bodies were not well founded in fact or law."

The Employment Appeal Tribunal had upheld the employment tribunal's finding that the BMA, although willing to support members in racism claims against employers, was not prepared to take on the royal colleges, their specialty advisory committees, the postgraduate deans, or the specialist training authority. This stance was held to amount to indirect discrimination because a disproportionate number of Asian members were affected.

Mr Chaudhary, aged 48, qualified in India in 1981 and came to the United Kingdom in 1987. He spent three and a half years as a registrar in urology in Manchester, moving to a locum senior registrar post. The post was said to be "royal college approved," and in 1992 it was listed by the Royal College of Surgeons as providing "acceptable training."

But when Mr Chaudhary applied to the postgraduate dean to be admitted to the specialist
the route to a consultant's post, he was told the Manchester job had not been approved by the specialty advisory committee for urology and that he would need a further 25 months' training.

Lord Justice Mummery said it was $\mathrm{Mr}$ Chaudhary's expectation that after a time in the Manchester post he would progress to senior registrar and eventually to consultant. But changes in training and qualification arrangements had an impact on his ambitions to advance to consultant.

"In our view, when the established facts are analysed, it can be clearly seen that the BMA had sound reasons for believing that Mr Chaudhary had been dealt with according to the rules and that there was no basis for suspecting that the decision had been tainted by either direct or indirect race discrimination."

\section{GPs work same hours but spend longer with their patients}

\section{Zosia Kmietowicz LONDON}

GPs in the United Kingdom are seeing fewer patients than they were 14 years ago but spending more time with each patient, a survey has shown.

The survey also shows that full time GP partners are working an average of 44.4 hours a week, similar to in 1992-3. The BMA has said that the longer consultations reflect the increasing complexity of general practice and the fact that GPs are treating more patients who used to be cared for in hospital.

Laurence Buckman, chairman of the BMA's GPs' committee, said, "What has changed is the way we work. Intensity has rocketed. Patient care that used to routinely take place in a hospital setting-such as diabetic care, cardiac care, and asthma care, is now routinely done in general practice. It used to be commonplace to be called to a child with uncontrolled asthma or a patient with heart failure and send them to hospital. Now it's a rare occurrence."

The survey was carried out by the NHS Information Centre on behalf of the four UK health departments, NHS Employers, and the BMA GPs' committee. Out of 4000 practices in the UK that were invited to take part, 329 returned diaries for their workload for one week in September or December 2006, recording the amount of time they spent on predefined activities.

The report says that it is difficult to make fair comparisons with the previous GP workload survey carried out in 1992-3 because so

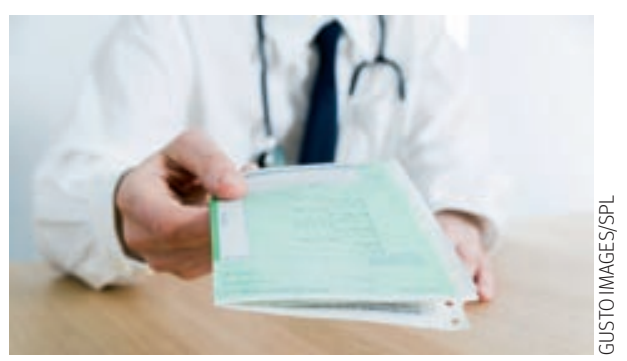

Full time GP partners are working an average of 44.4 hours a week

much has changed in the way that GPs work and are contracted. Different methods were also used for the surveys.

The 2006-7 UK General Practice Workload Survey is at www.ic.nhs.uk/pubs/gpworkload Trends in Consultation Rates in General Practice 1995 to 2006 is at www.ic.nhs.uk/pubs/gpconsultation 


\section{IN BRIEF}

Alcohol raises risk of bowel cancer: Two units of alcohol a day, equivalent to a pint of beer or a large glass of wine, increase risk of bowel cancer by about $10 \%$, says research based on the drinking habits of half a million people in 10 European countries. More than $30 \mathrm{~g}$ of alcohol a day increased their chances of developing the disease by $25 \%$ (International Journal of Cancer 2007 Jul 19 doi: 10.1002/ijc.22966).

Pfizer likely to face revised charges: The Nigerian government has withdrawn a \$7bn (£3.4bn; €5.1bn) civil lawsuit against Pfizer to refile the lawsuit with more serious charges over the use of an experimental drug, trovafloxacin, for the treatment of meningitis in children in Kano, Nigeria, in 1996 (BMJ 2007;334:1181). Pfizer says that the drug was in a late stage of development and had already been tested in more than 5000 patients.

\section{UK agency issues warning after floods: The Health Protection Agency has warned people in the United Kingdom affected by flooding that they risk poisoning from carbon monoxide if they use portable generators; camping stoves; or other gasoline, propane, or natural gas heaters that are meant for use outdoors in their homes. These devices should never be used to heat or dry out rooms, the agency says. Advice on how to safely clean houses after flooding is at www.hpa.org.uk}

German plans to force health checks over-ruled: The body that decides which tests and treatments should be reimbursed by the statutory insurance system in Germany has over-ruled a parliamentary decision to force patients with cancer who have missed regular screenings for cancers of the breast, bowel, and cervix to pay a larger part of the cost of treatment (BMJ 2006;333:877). Instead, it has recommended mandatory counselling on cancer screening.

Environmental factors cause $30 \%$ of children's diseases: Children's exposure to harmful chemicals at key stages of their development is as critical as the concentrations to which they are exposed, says the World Health Organization in a new report. Principles for Evaluating Health Risks in Children Associated with Exposure to Chemicals says that environmental factors account for more than $30 \%$ of disease in children worldwide www.who.int/ipcs/ publications/ehc/ehc237.pdfi).

\section{Donepezil helps patients with severe Alzheimer's disease}

Janice Hopkins Tanne NEW YORK

Patients with severe Alzheimer's disease who are living at home with family care givers and are treated with donepezil stabilise or decline more slowly than patients given placebo, according to a multinational, randomised, placebo controlled trial published in Neurology (2007;69:459-69).

Donepezil was approved by the US Food and Drug Administration last year for the treatment of severe Alzheimer's disease as well as mild to moderate forms. The Canadian authorities approved its use for severe forms of the disease in June 2007.

Sandra Black, of the University of Toronto and lead author of the paper, said that North American researchers were suspicious of the decision by the UK National Institute for Health and Clinical Excellence (NICE) not to fund donepezil for patients with mild Alzheimer's disease. She said that researchers thought it might slow decline in these patients. NICE only recommends its use in patients who have moderate Alzheimer's disease. And it recommends that the drug is stopped once the disease becomes severe.

The Neurology study shows that patients receiving donepezil maintained cognitive and global functions or declined more slowly than patients receiving placebo.

Dr Black said that patients given donepezil showed significant improvement compared with patients given placebo in the "severe impairment battery test" and in the "clinician's interview based impression of change plus," which includes care giver's input.

\section{Netherlands may punish youths who drink in public to tackle teenage alcohol misuse}

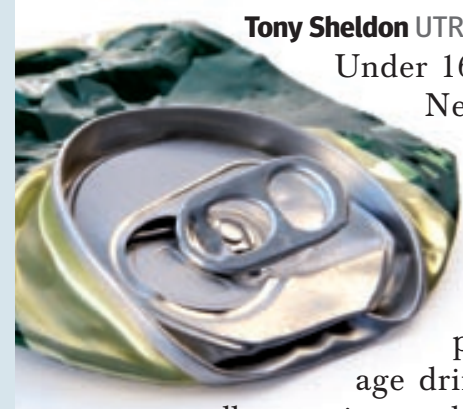

Under 16 year olds in the Netherlands could be fined for possessing alcohol in public as part of a crackdown against the rising problem of undercally targeting-and punishing-youths for possession, the proposals go far beyond most European countries' policies, such as UK bylaws to prevent drinking in public.

But with research that shows a trend towards young Dutch people drinking earlier 을 and more heavily, the Netherlands' Labour
Party, part of the governing coalition, says that it's time that national politicians took the lead in preventing cases of "booze, or alcoholic, coma."

The plan was launched in the Dutch parliament by the Labour MP Lea Bouwmeester, who wrote that Dutch youths are "undoubtedly among the European leaders when it comes to drinking at a very young age." She cites data from the Trimbos Institute of Mental Health and Addiction, which shows that $47 \%$ of 12 year olds had already tried alcohol and that $52 \%$ of 15 year olds drank alcohol every week (Nederlands Tijdschrift voor Geneeskunde 2006;150:2521-2).

The plan enjoys support from MPs in all three parties in the governing coalition.

\section{WHO database to include drug trials in}

\section{Caroline White LONDON}

Researchers, funders, and patients will soon be able to find out which clinical trials are being held in China and India, the World Health Organization announced last week.

Both countries, which are rapidly becoming key players in medical research, have joined the international network of government backed clinical trial registers, coordinated by WHO.

The network aims to boost accountability and transparency for global health research and to improve the quality of data.

Minimum standards of quality are required for entry to the network, said a spokesperson for WHO, adding that the International Committee of Medical Journal Editors has stipulated the registration of clinical trials before any participants are enrolled. WHO hopes that this acts as a strong incentive for companies and institutions to register their trials and acquire ethical approval. 


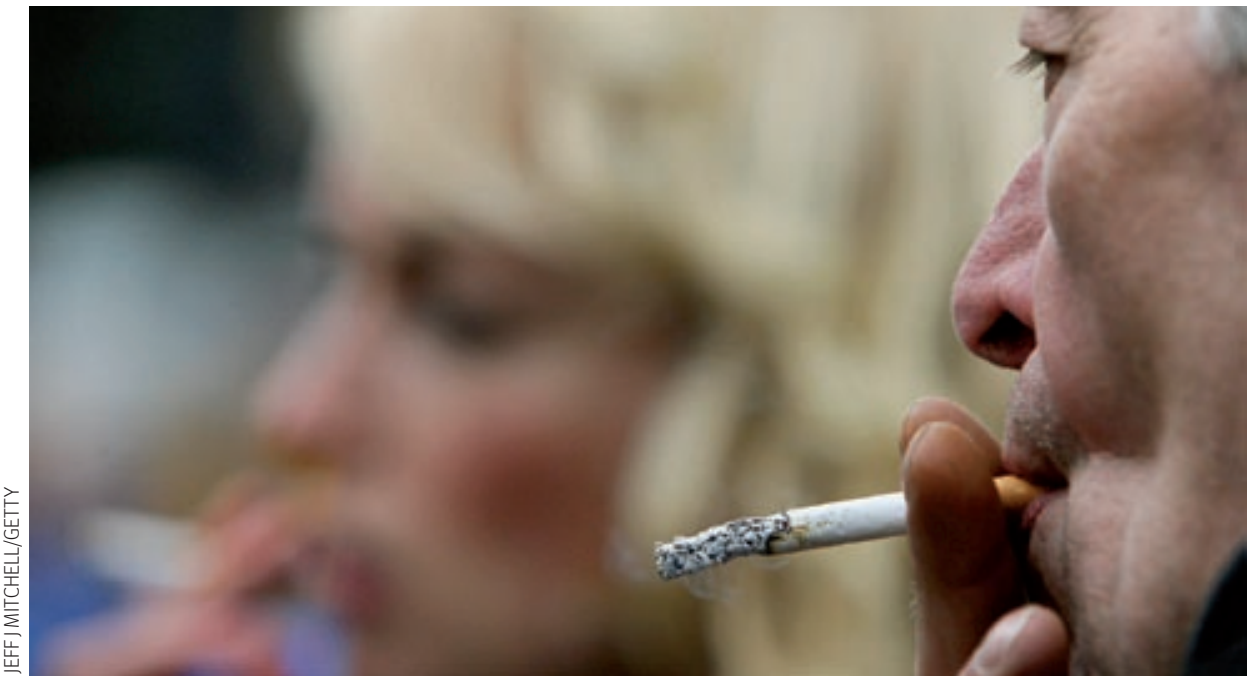

The incidence of lung cancer is $35 \%$ higher in Scotland than in the whole of the UK and UK wide is $50 \%$ higher in men

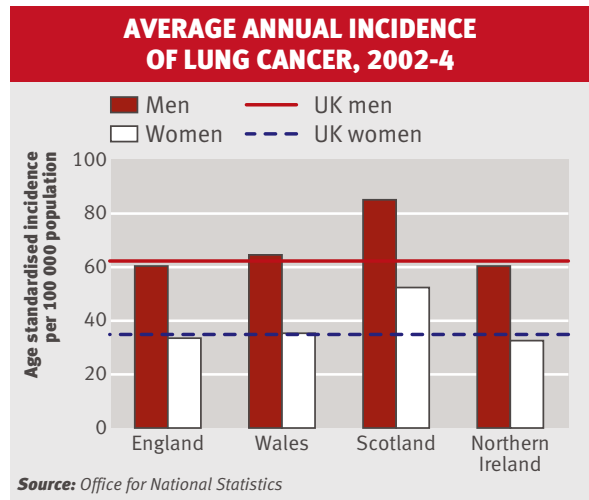

\section{Wales and Scotland have highest UK cancer rates}

\section{Roger Dobson ABERGAVENNY}

The incidence of lung cancer in Scotland is more than 35\% higher than in the United Kingdom as a whole, and overall is about $50 \%$ higher in men than in women. And the incidence of prostate cancer in Wales is $13 \%$ more than the UK average, according to a report from the Office of National Statistics for 2002-4.

Overall, there were about 278000 newly diagnosed cases of cancer and 154000 deaths from cancer each year in the UK between 2002 and 2004, says the report.

The three most common cancers for men were of the prostate, lung, and colorectum; for women they were of the breast, lung, and colorectum. Breast cancer in women had the highest incidence of all
(118 per 100000 ), almost 30\% higher than the incidence of prostate cancer (93 per 100000).

Lung cancer caused most mortality in men and women (56 and 30 per 100000 ). Breast cancer was the cancer that caused the second most deaths

\section{"Smoking causes around $90 \%$ of lung cancer cases and is linked to a range of other forms of cancer"}

in women (29 per 100000$)$, and prostate cancer was the cancer that caused the second most deaths in men (27 per 100000 ).

The report also shows considerable variation within the UK. Scotland had the highest overall incidence (446 for men and 379 for women per 100000$)$, and Wales had the second highest rate (450 and 366 per 100000$)$, compared with 394 and 338 per 100000 in England and 394 and 345 per 100000 in Northern Ireland. Scotland also had the highest overall mortality for cancer in the UK (262 and 182 per 100000$)$, followed by Wales, with 233 for men and 165 for women per 100000 .

In Scotland, mortality from cancer for both sexes was about $15 \%$ higher than in the UK as a whole, and the incidence of cancer was $10 \%$ higher. The incidence of lung cancer in men was higher than in women.

In Northern Ireland the incidence of breast cancer and associated mortality were the lowest in the UK, and the incidence of colorectal cancer and associated mortality were higher than the UK average.
Ruth Yates, head of statistical information at Cancer Research UK, said that although the incidence of cancer has been relatively stable in recent years, rates of death have fallen.

"This drop is mainly driven by a decline in smoking rates, alongside earlier detection and better treatment of cancers," she said. "Higher smoking rates in Scotland account for much of the difference in cancer rates between England and Scotland. Smoking causes around $90 \%$ of lung cancer cases, and is linked to a range of other forms of cancer, including oesophagus, mouth, and larynx."

She added, "We hope that the smoke-free laws will help further to drive down smoking rates." Cancer Incidence and Mortality in The UK 2002-2004 is available at www. statistics.gov.uk.

\section{China and India within "next few months"}

Access to the data, which WHO hopes to start publishing within the next few months, will be through a web based search portal that the agency set up in May this year www.who.int/trialsearch. The WHO spokesperson said that the move would make it easier to compare research in different countries and to find out who is sponsoring it and what questions are being asked. WHO's director general, Margaret Chen, said that the addition of the Chinese Clinical Trial Register and the Clinical Trials Registry in India represent a "milestone" in the move towards greater accountability.

"This development will contribute to improve the ethical conduct of, and public trust in, clinical trials," she added.

Phil Wiffen, associate director of the UK Cochrane Centre, agreed that the move was "a good thing" and would provide "more balance" by including negative and positive trial data.

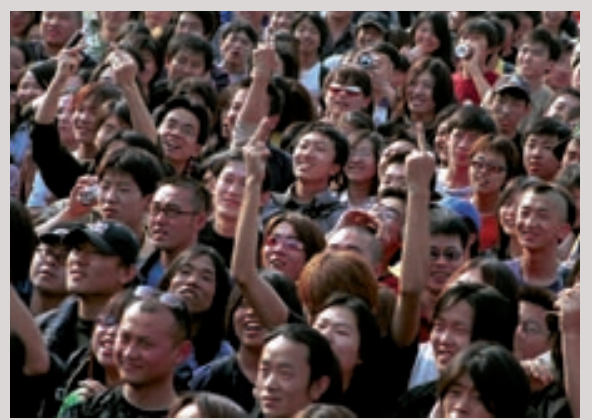

Drug trials in China and India should have better quality data 